\title{
Analysis on Corporate Environmental Disclosure Behaviors
}

\author{
Xuan CHEN \\ College of Economic \& Management, Shanghai Ocean University, Shanghai, 201306, \\ P.R. China
}

Keywords: Environmental disclosure, Environmental performance, Comparative analysis.

\begin{abstract}
This study explores some comparison on the composition of ED between Chinese companies and Norwegian companies are conducted. The current study finds: splitting the total ED into hard disclosure items and soft disclosure items, the soft/total disclosure scores are significant higher in poor environmental performers than in good environmental performers, especially facing the restrict regulations and limitation in management system, poor EP Chinese firms bend to conceal hard environmental information and good Chinese environmental performers are not zealous to convey "good" information to the public.
\end{abstract}

\section{Introduction}

Although, previous EP researches are abundant, the empirical association between the level of corporate ED and EP remains unresolved (Charl 2011) [1]. With the ratio of soft disclosure scores to total awarded scores as a proxy for environmental disclosure score, this paper presents comparisons of disclosure scores composition in the Norway and China. The results indicate:1) differences in soft to total disclosure ratios across good EP firms and poor EP firms show the ratio is significantly higher in poor EP firms than in good EP firms; 2) differences in soft to total disclosure ratios across China firms and Norway firms show the ratio is significant higher in poor EP Chinese firms than in other firms of the two countries, while the ratio is not significant in good EP Chinese firms than in other firms of the two countries.

\section{Background}

Norway is the first country requiring all firms by the Accounts Act (Regnskapsloven) to publish a clarification of whether they polluted the environment and to report executed and planned operations for appropriate environmental protection from 1989 (Even 2011). In 1999, a new Accounts Act was implemented, which made the requirements for ED more comprehensive. This accounts act requires firms to report environmental information on the entire product or service life cycle. Norwegian Accounting Standards Board made a preliminary standard, describing eight different conditions that are central to the external environment and, consequently, of importance to report (Norsk Regnskaps Stiftelse, 1999).

In the late 1970s, the Chinese government implemented an economic reform program to promote economic growth. The success of the program is evident with the growth in China's GDP averaging 9 percent per year since 2001. However, rapid development of China's economy incurred critical environmental issues. China's national development strategy for environmental protection has become more focused since the Sixth National Conference on Environmental Protection in 2006 (State Council, 2006). As a result, environmental disclosure is stressed by China's State Environmental Protection Administration (SEPA). For instance, in 2008, the government issued an advisory opinion on mandating corporate responsibility 
reporting according to the report to the United Nations Human Rights Council (UNCTAD, 2008a).

Since the founding of the stock exchanges in early 1990s, regulators in China have released several regulations aimed at improving corporate disclosure and reporting. However, most measures only focus on financial performance rather than environmental issues. Until recent years, there are no regulations stipulate companies to disclose information such as environmental management, pollutants discharge in their annual report.

Although China's environmental law enforcement is relatively weak compared to western countries, it is an indisputable fact that Chinese environmental regulation is increasingly getting stringent in the last couple of years. Under the setting of current environmental regulations and policy, poor environmental performers would suffer from fine or suspending production and other penalties posed by government. Their productive capacity expansion will also be subject to the limitations of industrial policy. These firms' direct or indirect financing could be refused by credit institutions and China Securities Regulatory Commission (CSRC). While current environmental policy regulates superior environmental performers would not only get governmental subsidies, financial rewards, or tax cuts and rebates in energy - saving or environmental preventive technology innovations, and they would also get encourage or supports from government in expansions of production capacity (Lu 2011)[2].

The above environmental regulations indicate that good Chinese environmental performers can get more comprehensive supports from government than other firms in two countries, while poor Chinese environmental performers face more rigorous penalty from government than other firms in two countries.

\section{Research Design}

\section{Variables}

Environmental Disclosure. According to the previous research, the score index of Clarkson (2008) [3] to measure ED is widely used. Therefore, our study adopt the score index of Clarkson (2008) [3] to measure ED. As Clarkson (2008)[3] has been pointed, items A1-A4 belong to hard disclosure, which are not easy to be mimicked by inferior environmental performers because all of them are easy to verify. Items A5-A7 belong to soft disclosure. The environmental disclosure index is scaled as three categories: Total Environmental Disclosure Index, Hard Environmental Disclosure Index and Soft Environmental Disclosure Index. Total Environmental Disclosure Index is calculated by the sum score of all the items in A1-A7 is divided by 95 . Hard Environmental Disclosure Index is count by the sum score of all the items in A1-A4 is divided by 79 and Soft Environmental Disclosure Index is computed by the sum score of all the items in A5-A7 is divided by 16. The ratio of soft disclosure scores to total awarded scores (Disclosure Scores Component, variable SOTOEDI) is used in the study to tests the influencing factors of environmental disclosure constitution.

Environmental Performance. The current study, takes whether a company is awarded ISO14001 certified as the proxy variable of firm's EP(variable EP). Because the implementation of ISO14001 environmental management system is voluntary for a firm, if the firm obtained the certificate, may indicate corporate management is extremely concerned about the environment and get good EP. In addition, the ISO14001 is a uniform international certification, avoiding some warp of evaluation standards in different countries to some extent. 
Dummy variable EP is assigned as " 1 " for those who is awarded ISO14001 certified, otherwise, EP is assigned as " 0 ".

Region. In this study, we use the regions where firms are registered as judgement standard for location (Variable ZONE), divided into two categories: "1"is assigned to Zone for Chinese companies; " 0 " is assigned to Zone for Norwegian companies.

Firm Type. To recognize the good environmental performers in Chinese stock exchange market, the study use variable GC to identify them. When the firm is good environmental performers in Chinese stock exchange market, variable GC is assigned as " 1 ", otherwise, it is assigned as "0". Similarly, variable PC is used to indentify those firms, who are poor environmental performers in Chinese stock exchange market. When the firm is poor environmental performer in Chinese stock exchange market, variable BC is assigned as " 1 ", otherwise, it is assigned as " 0 ".

Financial Performance. The previous studies use two methods to measure corporate financial performance. One is market-based methods such as stock market returns, etc. The other is accounting-based method such as profitability, return on assets, return on equity, and growth rate.

Considering China's stock market immaturity, especially deficiencies in China's stock market delisting system, stock price of some poor financial performance companies may be very high or go up quickly because of potential possibility of being reorganized. As a result, market - based variables cannot be used to objectively reflect real financial performance of a company in China. While accounting-based performance measurement variables better reflect corporate financial performance.

This study uses return on assets (variable ROA) to measure corporate financial performance, because it reflects comprehensive financial performance, even including unusual loss and gain.

Firm Size. Many empirical studies show firm size has an important influence on corporate environmental behaviors. The investment related to environmental protection would increase corporate operating costs. But, the increases in costs are varied with firm size. In addition, large companies get more concerns from regulatory agency and the public than small companies do.

This paper uses asset size as a proxy for business size (variable SIZE), which is the natural logarithm of the total asset value measured as of the end of fiscal year 2010.

Industry. Environmental behaviors of the industry to which a firm belongs determine the relationship between economy and environment. In this study, we selected firms from the fishery and shipping industries as sample. When firms are belongs to fishery industry, variable IND is assigned to " 0 ", while it is assigned to " 1 ".

Level. Financial leverage reflects the firm's financial status, determining the environmental management decisions. Variable LEV represents the leverage ratio, measured as the ratio of total liability divided by total assets at the end of fiscal year 2010 .

\section{Sample Selection and Data}

The sample of this study consists of all publicly listed Chinese companies and Norwegian companies from fishery industry and shipping industry in 2013. It contains 54 firms, including 26 firms listed in Shanghai or Shenzhen Stock Exchange Market and 27 firms listed in Oslo Stock Exchange Market. The sample industry distributes as follows: 31 firms in fishery industry and 23 firms in shipping industry. Among these firms, 13 firms are awarded 
ISO14001 certification and 40 are not awarded ISO14001 certification (Odfjell ASA didn't provide the related information) in fiscal 2013. All of data are from the 2013 annual reports provided on the related website and collect by hand.

\section{Analysis of Environmental Disclosure Composition}

In table 1, panel A provide the comparisons of soft to total disclosure scores across good environmental performers and poor performers in China and Norway respectively. As indicated in panel A, the ratio of soft/total scores is significant at $5 \%$ or $10 \%$ level. It means poor environmental performers are bent to release soft information and conceal hard information.

Panel B provide the comparisons of soft to total disclosure scores between different countries. As indicated in panelB, the ratio of soft/total scores is not significant at $10 \%$ level. It means the soft/total scores are not significant between Chinese firms and Norwegian firms.

Furthermore, the results of OLS regressions for the ratio of soft disclosure scores to total awarded scores are presented in Table 2.

Column (1) examines the effects of EP on the environmental score proportion. The estimated coefficient for EP is negative significant at $1 \%$ level, indicate the poor EP firms incline to release soft information and conceal hard information, which corroborates results in table 1 .

Column (2) tests the influence of ZONE on the ratio of soft disclosure scores to total awarded scores. The estimated coefficient for ZONE is not significant at $10 \%$ level.

Furthermore, column (3) compares the Chinese good environmental performers with other firms. The estimated coefficients for GC are not significant at $10 \%$ level.

Column (4) compares the poor EP Chinese firms with other firms. The estimated coefficients for PC are significant at $5 \%$ level. These results enunciate the location influence on the tendency of soft information releasing is limited: only those poor EP Chinese firms are significantly incline to conceal hard information, while its influence on Chinese good environmental performers is not significant.

The mimic characteristic of soft information facilitates understanding the above results. Legitimacy theory conceives that firms with threatened legitimacy are likely to make self-serving disclosures referred to as "legitimization" (Adams 2004[4], Gray et al. 1995[5], Hughes et al. 2001[6], Cheng 2010[7]). Considering the soft information is easy to mimic and manipulation, firms whose environmental legitimacy is threatened to make soft claims to be committed to the environment.

In addition, Chinese environmental monitor system and strict environmental regulations emphasize the hard information. It strengthens poor EP firms to conceal the hard information. 
Table 1. Comparisons of soft to total disclosure scores

\begin{tabular}{|c|c|c|c|c|}
\hline PANEL A & \multicolumn{2}{|c|}{ Average score } & \multicolumn{2}{|c|}{ Difference } \\
\hline & Good EP firms & Poor EP firms & $\begin{array}{c}\text { T-stat } \\
\text { (T value) }\end{array}$ & $\begin{array}{c}\text { Wilcoxon-stat } \\
\text { ( } \mathrm{Z} \text { value) }\end{array}$ \\
\hline \multirow[t]{2}{*}{ China } & 0.333 & 0.718 & \multirow[t]{2}{*}{$-2.578^{* *}$} & \multirow[t]{2}{*}{$-2.373^{* *}$} \\
\hline & 0.500 & 0.707 & & \\
\hline \multirow[t]{2}{*}{ Norway } & 0.304 & 0.619 & \multirow[t]{2}{*}{$-2.421^{* *}$} & \multirow[t]{2}{*}{$-2.264 * *$} \\
\hline & 0.209 & 0.714 & & \\
\hline \multirow[t]{2}{*}{ Total } & 0.315 & 0.667 & $3.644^{* * *}$ & $-3.274^{* * *}$ \\
\hline & 0.211 & 0.714 & & \\
\hline PANEL B & \multicolumn{2}{|c|}{ Average score } & \multicolumn{2}{|c|}{ Difference } \\
\hline & China & Norway & $\begin{array}{c}\text { T-stat } \\
\text { (T value) }\end{array}$ & $\begin{array}{c}\text { Wilcoxon-stat } \\
\text { (Z value) }\end{array}$ \\
\hline \multirow{2}{*}{$\begin{array}{l}\text { Poor EP } \\
\text { firms }\end{array}$} & 0.718 & 0.619 & \multirow[t]{2}{*}{-0.934} & \multirow[t]{2}{*}{-0.917} \\
\hline & 0.707 & 0.714 & & \\
\hline \multirow{2}{*}{$\begin{array}{l}\text { Good EP } \\
\text { firms }\end{array}$} & 0.333 & 0.304 & \multirow[t]{2}{*}{0.226} & \multirow[t]{2}{*}{-0.074} \\
\hline & 0.500 & 0.209 & & \\
\hline \multirow[t]{2}{*}{ Total } & 0.634 & 0.526 & \multirow[t]{2}{*}{1.301} & \multirow[t]{2}{*}{-1.121} \\
\hline & 0.667 & 0.500 & & \\
\hline
\end{tabular}

* Correlation is significant at the 0.10 level (2-tailed).

** Correlation is significant at the 0.05 level (2-tailed).

$* * *$ Correlation is significant at the 0.01 level (2-tailed)

Table 2. OLS regression on soft to total disclosure scores

\begin{tabular}{|c|c|c|c|c|}
\hline & SOTOEDI & SOTOEDI & SOTOEDI & SOTOEDI \\
\hline (Constant) & $2.030^{* * *}$ & $2.211^{* * *}$ & $2.216^{* * *}$ & $2.074^{* * *}$ \\
& 4.873 & 5.129 & 5.085 & 4.918 \\
\hline IND & 0.060 & 0.039 & 0.044 & 0.018 \\
& 0.598 & 0.373 & 0.416 & 0.172 \\
\hline ROA & $0.984^{*}$ & 0.953 & $1.079^{*}$ & 0.857 \\
& 1.705 & 1.556 & 1.766 & 1.448 \\
\hline LEV & 0.019 & 0.068 & -0.038 & 0.088 \\
& 0.081 & 0.263 & -0.148 & 0.355 \\
\hline SIZE & $-0.110^{* * *}$ & $-0.135^{* * *}$ & $-0.126^{* * *}$ & $-0.126^{* * *}$ \\
& -3.220 & -3.867 & -3.510 & -3.714 \\
\hline EP & $-0.267^{* * *}$ & & & \\
& -2.881 & & & \\
\hline ZONE & & 0.131 & & \\
& & 1.526 & & \\
\hline GC & & & -0.176 & \\
& & & -1.235 & \\
\hline PC & & & & $0.209^{* *}$ \\
& & & & 2.446 \\
\hline F Value & $5.601^{* * * *}$ & $4.358^{* * *}$ & $4.131^{* * *}$ & $5.390^{* * *}$ \\
\hline Adjust R square & 0.320 & 0.251 & 0.238 & 0.305 \\
\hline Size & 50 & 51 & 51 & 51 \\
\hline
\end{tabular}

* Correlation is significant at the 0.10 level (2-tailed).

** Correlation is significant at the 0.05 level (2-tailed).

$* * *$ Correlation is significant at the 0.01 level (2-tailed). 


\section{Conclusions and Discussion}

Consistency of style is very important. Note the spacing, punctuation and caps in all the examples below. Using a sample of 54 firms from the fishery and shipping industries listed companies in the Norway and Chinese, we find:

1) differences in soft to total disclosure ratios across good EP firms and poor EP firms show the ratio is significantly higher in poor EP firms than in good EP firms in both China and Norway.

2) differences in soft to total disclosure ratios across Chinese firms and Norwegian firms show the ratio for poor EP Chinese firms is significant higher than other firms in two countries.

The above results indicate the restrict penalty to the poor EP firms and the unilateral pursuing GDP of local government result in the poor EP firms to conceal the environmental information. Especially, the management mechanism for Chinese state-owned facilitates the conspiracy between firms and government, which tampers the efficiency of restrict environmental regulations.

\section{Acknowledgement}

This research has been fund by Ministry of Education of the People's Republic of China (No. 12YJC630016)

\section{References}

[1] C.D.Villiers, V.Naiker, The effect of board characteristics on firm environmental performance, Journal of Management. 37(2011) 1636-1663.

[2] J.Lu, The relations among environmental disclosure, environmental performance and financial performance: an empirical study in China, Joumal of Shanxi Finance and Economics University. 33(2011)109-116.(in Chinese)

[3] P.M.Clarkson, Revisiting the relation between environmental performance and environmental disclosure: An empirical analysis, Accounting, Organizations and Society. 33(4-5) (2008)303-327.

[4] C.Adams, The ethical, social and environmental reporting performance portrayal gap, Accounting, Auditing and Accountability Journal. 17(2004)731-757.

[5] R.Gray, R.Kouhy, S.Lavers, Corporate social and environmental reporting: A review of the literature and a longitudinal study of UK disclosure, Accounting, Auditing and Accountability Journal. 8(1995)47-77.

[6] H.C. Charles, M. Giovanna, P.M.Dennis. CSR disclosure: the more things change...? , Auditing \& Accountability Journal, 28(2015)14-35.

[7] L. H.Cheng, H. K.Fan, Drivers of environmental disclosure and stakeholder expectation: evidence from Taiwan, Journal of Business Ethics. 96(2010)435-451. 